\title{
An overview of the recent research on the Chukchi Sea water masses and their circulation
}

\author{
Maria N. Pisareva ${ }^{1}$ \\ Received 17 April 2018; accepted 23 August 2018; published 31 August 2018.
}

During the last decade of rapid environmental change in the Arctic multiple studies have been conducted in the region of the Chukchi Sea and Bering Strait, which is the only Pacific-Arctic oceanic gateway. Current paper provides an overview of the research based on the recent in-situ hydrographic observations in the Chukchi Sea. We discuss the properties of the major water masses, their pathways on the shelf and at the shelfbreak, and changes in the circulation patterns. Anomalously strong northerly winds account for the transposition of the water masses in Bering Strait, as well as cause the Alaskan Coastal Current flow into the Herald Canyon. Previously unknown Chukchi Slope Current has been described emanating from the Barrow Canyon and flowing westwards over the upper continental slope. Mutliple studies discuss the variability of the Pacific Winter Water on the shelf and at the shelfbreak; the circulation of the Pacific Winter Water on the shelf has been revised. Atlantic Water has been observed far south on the Chukchi shelf associated with high polynya activity in the region. KEYWORDS: Chukchi Sea; Chukchi Slope current; water masses; Bering Strait; Alaskan Coastal Current.

Citation: Pisareva, Maria N. (2018), An overview of the recent research on the Chukchi Sea water masses and their circulation, Russ. J. Earth. Sci., 18, ES4005, doi:10.2205/2018ES000631.

\section{Introduction}

The northward flow that is dominating the hydrographic regime in the Bering Strait, which is the only oceanic gateway between the Pacific and the Arctic oceans, has been known since the observations by Vitus Bering in the 18th century. Since that time the research on the physical conditions and ecosystem of the Bering Strait region and Chukchi Sea has been ongoing. However due to the remote location of the sea, harsh winter conditions, large atmospheric and oceanic variability, seasonal sea ice cover, and logistics around the Russian-US convention line, some of the precise pathways and transformations of the Pacific-origin water masses

\footnotetext{
${ }^{1}$ Shirshov Institute of Oceanology, Russian Academy of Sciences, Moscow, Russia

Copyright 2018 by the Geophysical Center RAS. http://rjes.wdcb.ru/doi/2018ES000631-res.html
}

on the Chukchi shelf still need verification. Constant monitoring of the Chukchi Sea hydrography is especially essential in the decade of accelerated climate change in the Pacific Arctic [Wood et al., 2015 and reducing sea ice cover [Carmack et al., 2016 .

The inflow of Pacific-origin water northwards through the Bering Strait is known to strongly influence both physical properties and the ecosystem of the entire Arctic Ocean. It is a great source of freshwater [Woodgate et al., 2012, heat [Steele et al., 2004], and nutrients [Lowry et al., 2015] to the Arctic, contributing to ice-melt, ventilating the halocline [Pickart et al., 2005], spurring primary production in the region. The Chukchi Sea, in turns, is an important transition region for the Pacific waters entering the Arctic Basin. The flow of Pacific-origin waters undergoes significant transformation on the Chukchi shelf due to the seasonal presence of ice, shallow topography (mean depth of 
the Chukchi Sea is $50 \mathrm{~m}$ ), as well as atmospheric forcing.

The increase in the mean northward transport through the Bering Strait (caused by the pressurehead difference between the Pacific and Arctic oceans and local winds) from $0.7 \mathrm{~Sv}$ to $1.1 \mathrm{~Sv}$ over the past decade drives the increase of heat and freshwater fluxes [Woodgate et al., 2012. The dramatic corresponding consequences include, but are not limited to enhanced ventilation of Pacific Arctic halocline, thinning and retreat of the sea ice $[S h i-$ mada et al., 2006, triggered ice-albedo feedback [ Woodgate et al., 2012, 2015, significant shift in the timing of sea ice melt and freeze onset and overall increase in environmental variability [Wood et al., 2015. Woodgate et al., 2015.

The current study describes recent hydrographic research done in the Chukchi Sea and presents an overview on the new insights of the schematic circulation patterns on the shelf and at the shelfbreak. This overview describes the research done with the use of multiple data sources: three large biophysical surveys and moorings of Russian-American Long-term Census of the Arctic (RUSALCA) of 2004, 2009, and 2012 [Linders et al., 2017, Pickart et al., 2010, Pisareva et al., 2015a, 2015b, the survey of the International Siberian Shelf Study program in 2008 [Anderson et al., 2011; Linders et al., 2017, hydrographic and velocity data from 46 publicly-available shipboard sections carried out during the period 2002-2014 across the Chukchi shelfbreak/slope (cruises on USCGC Healy, USCGC Polar Star, R/V Nathaniel Palmer; see [Corlett and Pickart, 2017], a series of year-long moorings deployed in the eastern Chukchi Sea in 2010-2011, 2014, and 2015 [Ladd et al., 2016, a year-long mooring array on the outer shelf and continental slope in the northeastern Chukchi Sea from 2013 to 2014 [ Li and Pickart, 2017, data in the Eastern Chukchi/Western Beaufort Seas from 2002-2004 Western Arctic Shelf-Basin Interactions (SBI) program [Lin et al., 2018, Pisareva et al., 2015b, data from the 2010-2011 Impacts of Climate on Ecosystem and Chemistry of the Arctic Pacific Environment (ICESCAPE) program [Pickart et al., 2016], supplemented with data from WOD database (https://www.nodc.noaa.gov; see [Pisareva et al., 2015a.

\section{Water Masses of the Chukchi Sea}

Pacific-origin waters, flowing northward are believed to follow three topographically steered pathways on the Chukchi shelf (Figure 1). Summer Bering Sea Water (BSW; $\theta=\sim 0-3^{\circ}, S=\sim 32-33$ psu), which is a product of mixing of nutrient-rich Anadyr Water and colder and fresher Bering Shelf Water [Coachman et al., 1975, divides into two branches north of the Bering Strait. One branch progresses through the Herald Canyon and the second branch - through the Central Channel [Weingartner et al., 2005, after which it is diverted eastward into the Barrow Canyon. There have been also evidences of another pathway of the BSW through the Long Strait westward into the East Siberian Sea [Weingartner et al., 1998. Woodgate et al., 2005a, but this pathway has not been established as a permanent branch.

While some studies [Woodgate et al.,2005a] suggest, that the mean volume transport in each of the three main flow branches is similar, recent shipboard data show that during summertime the Barrow Canyon can account for up to $80-100 \%$ of the Bering Strait inflow [Gong and Pickart, 2015. Itoh et al., 2013, Pickart et al., 2016.

In winter this water mass is transformed into the Pacific Winter Water (WW, also known as "Newly Ventilated Pacific Winter Water"; $\theta<\sim-1.6^{\circ}$ ) by convective overturning that lowers the temperature to near the freezing point. It can be also formed and modified within polynyas (e.g. in the Northeast Chukchi Sea polynya or in the vicinity of Wrangel Island), leads and small openings on the Chukchi shelf, as well as mixed along the pathways on the shelf [Gong and Pickart, 2015]. As a result of extreme salinization due to brine rejection Pacific Winter Water can be further transformed into Hypersaline Winter Water (HSWW; $\theta<\sim-1.6^{\circ}, S>\sim 34 \mathrm{psu}$ ) [Itoh et al., 2015, Weingartner et al., 1998. In spring and summer solar heating and/or mixing with summer waters modify the WW into a product called Remnant Winter Water (RWW; $\theta=\sim-1.6-0^{\circ}, S>\sim 31.5-34$ psu), which temperature is no longer near the freezing point.

In the eastern part of the Chukchi Sea warm and fresh Alaskan Coastal Water (ACW; $\theta>\sim$ $2-3^{\circ}, S<\sim 32 \mathrm{psu}$ ) follows the Alaskan coast northward to the Barrow Canyon from late-spring 


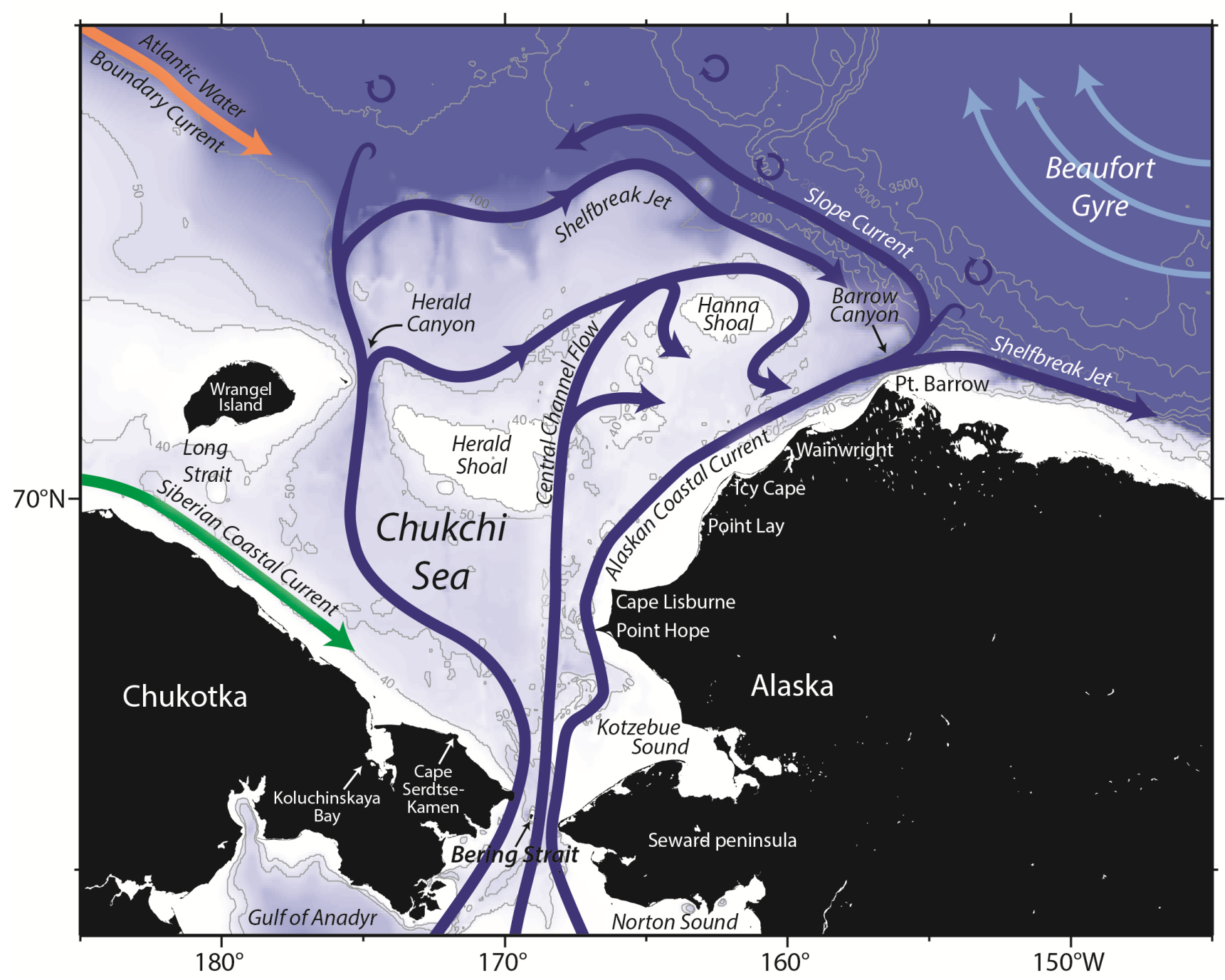

Figure 1. The most recent scheme of the Chukchi Sea circulation and geographical place names. Siberian Coastal Current is shown in green, the lateral distribution of the Pacific-origin water is shown in blue. Adopted from [Corlett and Pickart, 2017; Pisareva et al., 2015a, 2015b; Brugler et al., 2014.

until early-autumn [Paquette and Bourke, 1976]. It originates from the river run-off into the Gulf of Alaska and eastern Bering Sea, enters the Chukchi Sea through the eastern side of the Bering Strait, and forms a narrow $(\sim 10-20 \mathrm{~km}$ wide), surfaceintensified Alaskan Coastal Current (ACC).

In addition to Pacific-origin waters, there are also water masses of the Atlantic and local Arctic origin in the Chukchi Sea. Atlantic Water (AW; $\theta>\sim-1.26^{\circ}, S>33.64 \mathrm{psu}$ ) the boundary between the Pacific and Atlantic waters in the Chukchi Sea is usually taken as the depth of maximum Ertel potential vorticity, following [Nikolopoulos et al., 2009] is advected in a boundary current from the Fram Strait and Eurasian Basin, and modified on its long pathway towards Pacific Arctic [Rudels et al., 2004. It is usually found underneath the layer of Pacific Winter Water deeper than 180-200 $\mathrm{m}$ in the Canada Basin [Lin et al., 2018, Nikolopoulos et al., 2009, as such it is brought onto the Chukchi shelf during upwelling events in the Barrow and Herald canyons [Aagaard and Roach, 1990, Coachman et al., 1975, Pickart et al., 2010. 
Fresh and typically cold Siberian Coastal Water (SCW; $S<\sim 30 \mathrm{psu}$ ) originates from the river runoff into the Russian Arctic seas. East Siberian Sea rivers, inflow of the Laptev Sea water and discharge from the Lena River are all thought to contribute to the formation of this quasi-permanent current, flowing southeastwards along the Russian coast [Weingartner et al., 1998]. Two modes of the Siberian Coastal Current (SCC) are usually distinguished, influenced by the winds: westerly (downwelling favorable) winds create a sharp hydrographic front and the SCC is well-developed, while when the winds are easterly (upwelling favorable), the front is less distinct and the current is weakened or absent at all. Upon reaching the Bering Strait the current is believed to veer offshore and mix with ambient waters, although occasionally the SCW has been measured south of the strait [Weingartner et al., 1998].

Meltwater/river runoff (usually defined by the 24 $\mathrm{kg} \mathrm{m}{ }^{3}$ isopycnal; Linders et al., 2017) is typically observed in the upper part of the water column (usually shallower $15 \mathrm{~m}$ ) and has a large range of temperatures depending on the time of year. With the use of specialized tracers (e.g. stable oxygen isotope O-18; see [Cooper et al., 1997]), it is possible to determine the river runoff vs ice melt origin for this water mass, however such analysis is not always performed.

One should note, that while the flow pathways of water masses in the Chukchi Sea are well established, this does not imply that the flow remains constant from the Bering Strait into the canyons. While waters tend to follow bathymetry, they are also very sensitive to a number of physical drivers, as well as depend on the inflow through the narrow and shallow Bering Strait. Pisareva et al. 2015b have presented a depth-integrated flow speed map of the Chukchi Sea, derived from various shipboard ADCP data collected during the last decade, where revealed, that due to high variability of the hydrography and flow on the shelf this pathways appear somewhat patchy. Nevertheless, clear patterns are evident and they repeat the known general scheme very well. Likewise, one should be cautious in defining the water mass boundaries as the characteristics of the shelf waters change from year to year [Pisareva et al., 2015a]. The above mentioned TS characteristics should be considered as guidelines and one should look for the distinct core of each water mass instead.

\section{Lateral Pathways on the Chukchi Shelf}

While multiple cruises are conducted in the Chukchi Sea every year, RUSALCA surveys of 2004, 2009, and 2012 were the most extensive in the western part of the Chukchi shelf. Based on the collected data [Pisareva et al., 2015a, 2015b have constructed lateral distributions of different water masses for each of the survey. Along with usual temperature, salinity, nutrient data (along with SST maps, measured depth and geographic location) used for identifying the water masses, zooplankton communities have been used. As zooplankton in the pelagic system respond very rapidly to changes in the physical forcing, it provides us with an additional indicator of water masses origin (for the details see [Pisareva et al., 2015b). Extensive quasi-synoptic surveys of the Herald Canyon during RUSALCA cruises (2004, 2009, 2012), as well as 2008 survey of the International Siberian Shelf Study program [Anderson et al., 2011. Linders et al., 2017 have shed light on the canyon water masses and their dynamics [Pickart et al., 2010 Pisareva et al., 2015a; Linders et al., 2017. Here we review the revealed lateral pathways for each of the water masses on the Chukchi shelf.

\subsection{Alaskan Coastal Water}

During August 2004 Alaskan Coastal Water was flowing northward through the eastern part of the Bering Strait and distributed broadly across the southern part of the Chukchi shelf all the way to the Chukotka coast (Figure 2a). Zooplankton data supports the presence of the ACW on the southern sections along the Alaskan coast, but also surprisingly shows the appearance of the ACW on the eastern side of the Herald Canyon (evident in the TS space as well; [Linders et al., 2017; Pisareva et al., 2015b. The same situation has been observed again in September 2008 [Linders et al., 2017 and September 2009 Figure 2b; [Pisareva et al., 2015a). Pisareva et al. 2015a explained, that strong northerly winds can divert the ACW onto the western Chukchi shelf and into the Herald Canyon. However during August 2004 southeastern winds prevailed, hence we could not use this dynamical explanation for the presence of the ACW on the western shelf and in the Herald Canyon. 

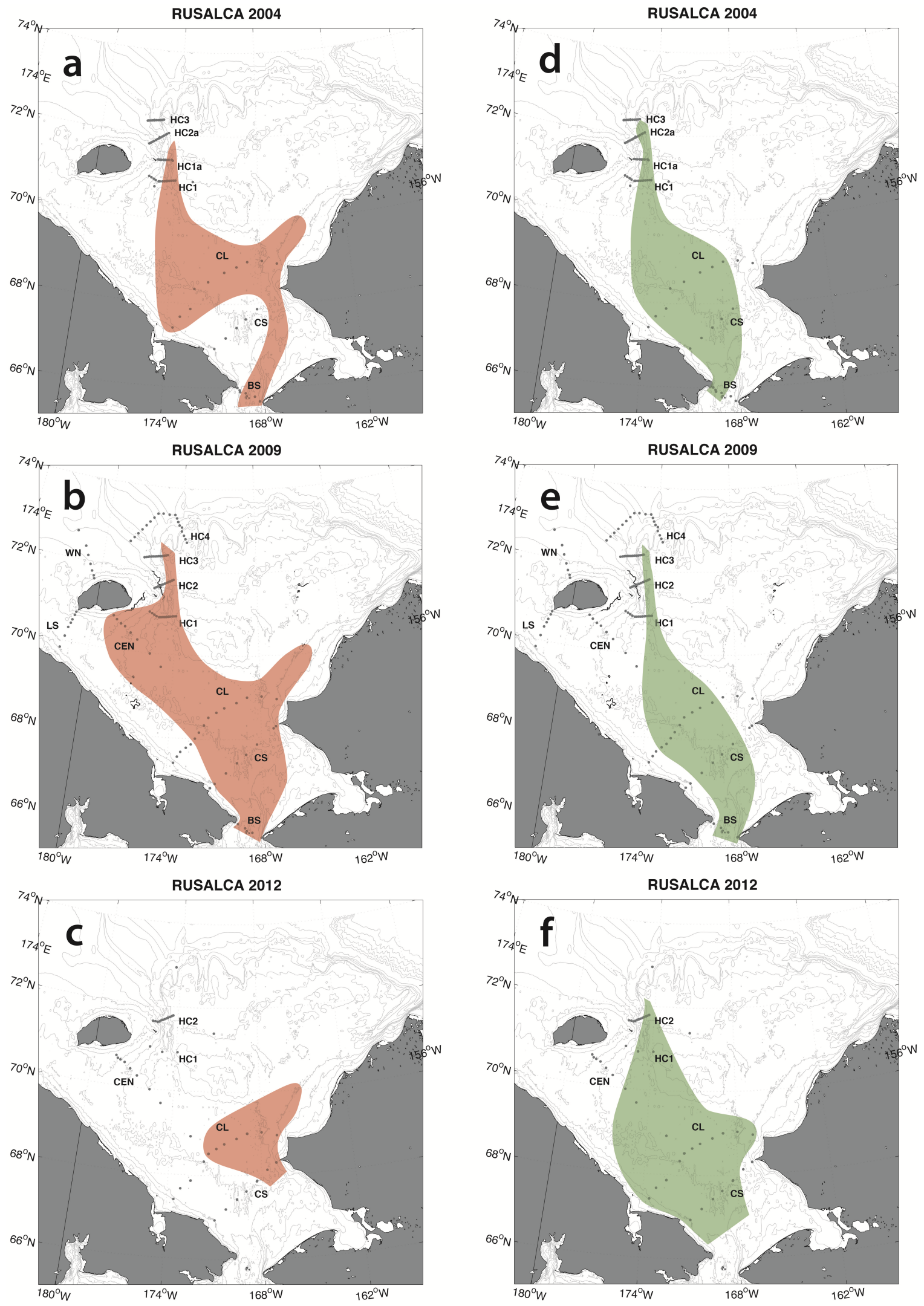

Figure 2. Lateral distributions of Alaskan Coastal Water (a, b, c) and Summer Bering Sea Water (d, e, f) during the RUSALCA surveys. For the geographical place names see Figure 1. Adopted from [Pisareva et al., 2015b]. 
Another surprising aspect of September 2009 survey was the transposition of the ACW and the BSW in the Bering Strait (Figure 2b), which also happened due to the Ekman transport under the influence of anomalously strong northerly winds. As a result, the BSW was forming a compensating current at depth in the Bering Strait, hence appeared near the Alaskan coast (Figure 2 ). With the use of an idealized configuration of the MITgcm primitive equation model [Marshall et al., 1997], Pisareva et al., 2015a have identified a threshold of the windstress integral, for such transposition to happen (for the description of the model and simulation the reader is referred to [Pisareva et al., 2015a). It appears that strong northerly events exceeding the threshold happened prior both to the 2008 and 2009 surveys. Authors suggest that such deviation of Alaskan Coastal Water towards the Russian side of the Bering Strait can be observed more often in the winter period, but lack of in situ measurements during wintertime did not allow us to sample this phenomenon before.

During September 2012 the winds were even greater than in September 2009 (though steadier), and during one event time integral of the wind stress has reached the threshold for water mass transposition in the strait, but at that time the ACW was found confined to the Alaskan coast, following its usual pathway (Figure 2k). While the reasons for this are yet to be explored, we can suggest that possibly the vast SCC observed during the survey or large amounts of sea ice present on the shelf could have prevented the Ekman transport of the ACW.

Upon reaching the northern part of the shelf the Alaskan Coastal Current exits the Chukchi Sea through the Barrow Canyon. Under the influence of easterly winds the current can be displaced to the western side of the canyon [Brugler et al., 2014, Okkonen et al., 2009, which supports the recent studies [Corlett and Pickart, 2017], showing that during summertime the ACC most likely turns to the west in the surface-intensified Chukchi Slope Current (see Section 4).

\subsection{Summer Bering Sea Water}

Apart from the transposition in the Bering Strait in September 2009 (Figure 2 $)$, the lateral distribution of summer Bering Sea Water was consis- tent with the known summertime pathways during all three RUSALCA surveys (Figure $2 \mathrm{~d}, \mathrm{e}, \mathrm{f})$ and the survey of 2008: it progressed to the northwest through the Central shelf into the Herald Canyon. There the warm BSW was found residing on the eastern flank of the canyon, while its western flank was occupied by dense modes of Winter Water. By tracking the BSW flowing from the western side of the Bering Strait into the Herald Canyon during summer months [Linders et al., 2017] have calculated typical advective speed of $10-20 \mathrm{~cm} / \mathrm{s}$, which corresponded to the estimated travel time of 1.2 - 2.3 months based on model results and current meter measurements [Spall, 2007] Woodgate et al., $2005 \mathrm{~b}$. The transport of both ACW and BSW decreases substantially along their pathways into the Herald Canyon and none of the water masses was found near the mouth of the canyon [Pisareva et al., 2015a.

The least amount of the BSW in the Herald Canyon was observed during the survey of August 2004, when this water mass did not reach the northernmost section of canyon [Linders et al., 2017. Pickart et al., 2010. Pickart et al. 2010] explain it either by mixing due to the cross-channel circulation or by the lack of measurements further on the eastern flank. During September 2012 the BSW was closer to the Alaskan Coast compared to the two other years (compare Figure $2 \mathrm{~d}, \mathrm{e}, \mathrm{f}$ ).

Corlett and Pickart 2017 claim, that during summertime the off-shelf BSW is to a large degree advected by the Chukchi Slope Current (see Section 4 ), while only moderately present in the Chukchi shelfbreak jet (only $5 \%$ of the total volume flux).

\subsection{Pacific Winter Water}

Pacific Winter Water in August 2004, September 2008, September 2009 and September 2012 has followed the known summertime configuration: it was observed in the Herald Canyon and around Wrangel Island (Figure 3a,b,c; see [Pickart et al., 2010 Pisareva et al., 2015a, 2015a, Linders et al., 2017]). A large portion of the recently ventilated WW was measured entering the canyon on the western flank and, as it progressed northward down the canyon in a bottom-intensified flow, gradually transposing to the eastern flank of the canyon (same situation was documented by Pickart et al. 2005] in the Barrow Canyon) due to the occurrence 

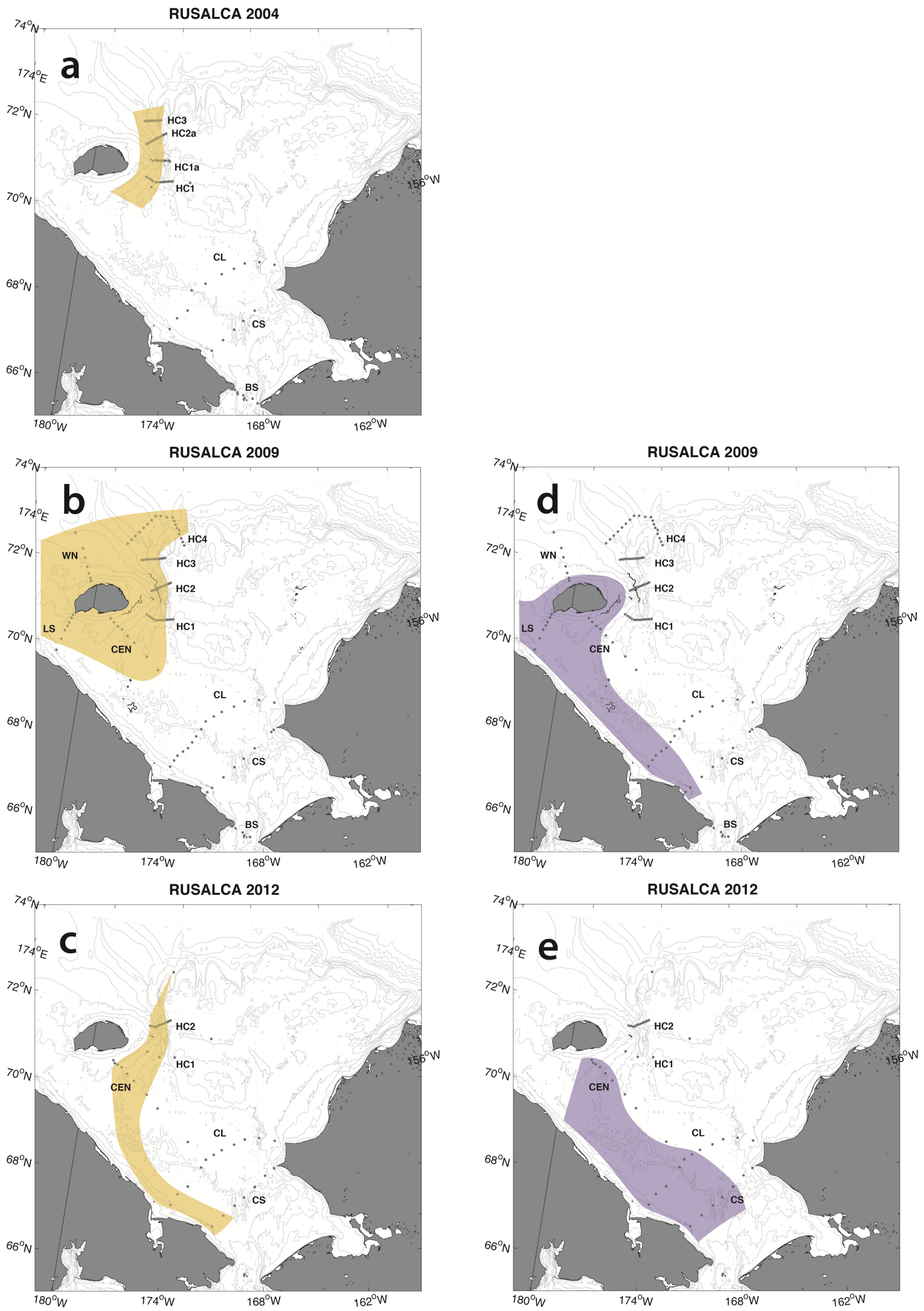

Figure 3. Lateral distributions of Pacific Winter Water (a, b, c) and Siberian Coastal Water (d, e) during the RUSALCA surveys. For the geographical place names see Figure 1. Adopted from [Pisareva et al., 2015b. 
of hydraulic activity within the canyon [Pickart et al., 2010.

The largest amount of the newly ventilated WW was observed in 2004, during the warmest period, compared to other surveys [Pisareva et al., 2015b. Wood et al.,2015. During the cruise of 2008 less of the WW was found and its amount increased from south to north [Linders et al., 2017]. The same situation was observed in September 2009, when the newly ventilated WW was present only at the northernmost section (HC4) across the mouth of the canyon, while the RWW was instead residing at the head and along the length of the canyon. While one of the obvious explanations for such differences is seasonal variability (the 2004 survey happened in late-August, while the 2008 and 2009 surveys were later in September), multiple mechanisms can influence water mass distribution and advection on the shelf.

Both long-term wind forcing and storms could have impacted the flow, prolonging the residence time of Winter Water on the shelf (such as strong northerly winds during winter/spring 2004 [Linders et al., 2017. Weingartner et al., 1998]), or contributing to the enhanced presence of Winter Water at the northern reaches of the canyon (e.g. strong northwesterly winds near the time of 2008 and 2009 surveys (Pickart et al., 2010]). By tracking the Winter Water mode from the mooring data in the Bering Strait Linders et al. 2017 have provided evidence, that the Bering Strait is likely a direct source of the WW, found at the southern sections of the Herald Canyon in 2004 (with the travel time of about $\sim 4.5$ months corresponding to an advective speed of the WW of $5-8 \mathrm{~cm} / \mathrm{s}$ ). However, the Bering Strait is not the only source of the WW in the Herald Canyon. Pickart et al. 2010 suggested that in 2004 the newly ventilated WW was formed within a polynya on the northwestern side of Wrangel Island, advected by the prevailing anticyclonic circulation around the island and draining into the western side of the canyon head. While the investigation by Linders et al. 2017 has shown no obvious connection between the winter polynyas of 2004, 2008, and 2009 and the presence of the Winter Water in the Herald Canyon, this linkage can be overpowered by the wind-driven variability on the shelf. Linders et al. 2017] also discussed, that the origin of the newly ventilated Winter Water in the canyon in 2008 would likely be the East Siberian shelf, as large warming of the Winter Water would be implied on its way from the Bering Strait.

While heavy ice conditions unfortunately did not allow us to sample the northernmost sections (HC3, HC4) during September 2012, at that time Winter Water was not only present in the Herald Canyon, consistent with the previous surveys, but also it was observed for the first time flowing northward along the Chukotka coast in the CL and CS transects during summertime (Figure 3c.

Using early-summer shipboard data from the 2010-2011 ICESCAPE program [Pickart el al. 2016 have constructed a revised circulation scheme of the transport pathways of Pacific Winter Water in the northeastern part of the Chukchi shelf Figure 4). The circulation pattern was found to be more complex, than previously anticipated. Arriving in the northern part of the shelf via the Central Channel pathway, Winter Water was found turning to the east, flowing around both sides of the Hanna shoal and dividing into smaller filaments that continued towards the Barrow Canyon. During JuneJuly 2011 [Pickart et al. 2016] have also documented salinization of the progressed upstream WW, due to brine rejection in the Cape Lisburne polynya, providing another evidence of the WW transformation within the Chukchi shelf.

Upon reaching the shelfbreak and exiting the sea through the canyons Pacific Winter Water is thought to either turn to the east and comprise a shelfbreak jet along the edge of the Chukchi Sea [Corlett and Pickart, 2017, Pickart et al., 2010] and Beaufort Sea [Brugler et al., 2014 Nikolopoulos et al., 2009, or be fluxed directly into the basin via turbulent processes (e.g. via eddies - observed in 2009, [Pisareva et al., 2015a, Pickart et al., 2010. It is possible, that small amounts of the WW can be involved in the Chukchi Slope Current as well (see Section 4), but more year-round investigations are needed [Corlett and Pickart, 2017]. Winter Water can also be advected southwards up the canyon, as was observed in 2004 or 2008. Data from the mentioned surveys suggests that both times dense Winter Water was entering the mouth of the canyon on its western flank. Linders et al. 2017 speculated, that this water emanated from a shelfbreak current along the East Siberian Sea, while formed on the East Siberian shelf (see also [Anderson et al., 2011], however an upwelling of the WW back into the canyon after it has been previously drained through it is also a possibility. 


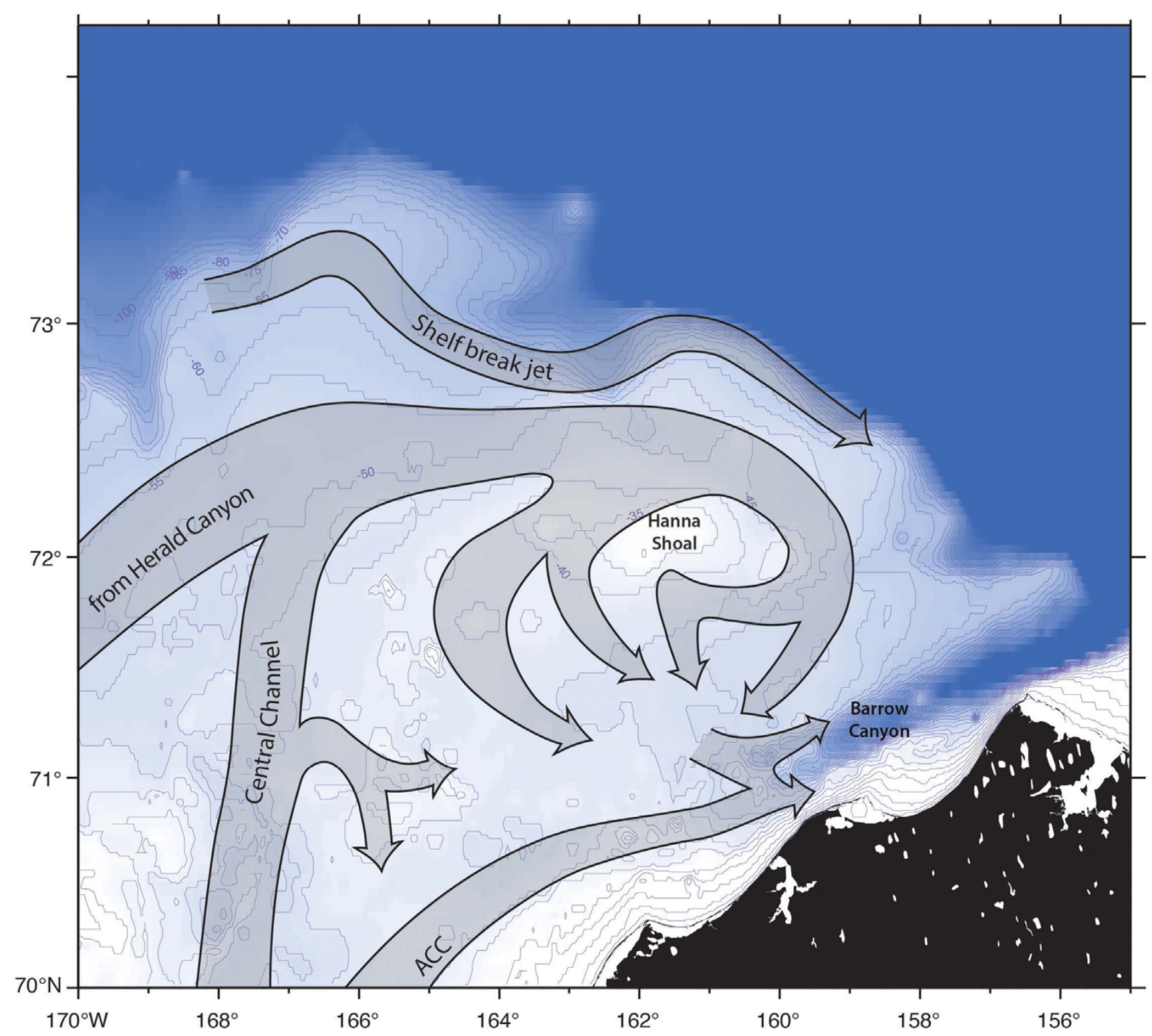

Figure 4. Winter Water flow pathways on the northeastern Chukchi shelf from 20102011 shipboard data. Adopted from [Pickart et al., 2016].

\subsection{Siberian Coastal Water}

Vast Siberian Coastal Current was observed both in 2009 and 2012 following the Chukotka coast towards the Bering Strait, in accordance with the Siberian zooplankton clusters (Figure 3 d,e). In 2009 for the first time it was unexpectedly measured being involved in an anticyclonic circulation around Wrangel Island [Pisareva et al., 2015a, 2015b. Linders et al. 2017 have even argued that some of the SCW was observed in the Herald Canyon during September 2004 survey (western flank of section HC2a), implying, that while circulating around Wrangel Island it can get diverted into the Herald Canyon. As Siberian Water was also observed along the Central Chukchi (CEN) section in 2012, Pisareva et al. 2015b suggested, that it was likely circulating around Wrangel Island, as was the case in 2009.

It is worth to mention the anomalous nature of the station closest to Koluchinskaya Bay on the Chukotka coast: waters colder than the BSW $\left(<-1.4^{\circ} \mathrm{C}\right)$, but fresher than the WW have been observed there during the surveys of 2004 and 2009. 
It was suggested, that these waters emanate from Koluchinskaya Bay, after they appeared there earlier. Therefore, they contained different zooplankton species, not associated with the physical characteristics of the flow dominating in the region at the moment.

\subsection{Atlantic Water and Meltwater/River Runoff}

Atlantic water mass is not very often addressed in the studies of the hydrography of the Chukchi Sea, as its appearance on the shelf is quiet sporadic. Oftentimes it is brought on the Chukchi shelf via upwellings in the Barrow and Herald canyons [Itoh et al., 2013, Ladd et al., 2016 Pickart et al., 2010. Lin et al. 2018 have shown, that due to the influence of two regional centers of action - the Aleutian Low and the Beaufort High - seasonal changes in wind stress curl alter the Pacific - Atlantic Water interface depth. As such events occur during wintertime the AW is more readily available for the upwelling events.

During 2008 and 2009 surveys Atlantic Water was found residing at the northernmost sections in the Herald Canyon [Linders et al., 2017, Pisareva et al., 2015a. However sometimes Atlantic Water can be transported farther southwards on the Chukchi shelf. The earliest measurements of it being close to the Icy Cape go back to 1922, 1958, and 1975 [Bourke and Paquette, 1976], but recently Ladd et al. 2016 have described five such events on the basis of 2010-2011, 2014, and 2015 mooring data, suggesting that the AW regularly reaches farther onto the shelf than previously observed. Such occurrences of Atlantic Water are very important to the dynamics of the sea, as they can influence the formation and maintenance of the Northeast Chukchi Sea Polynya [Ladd et al., 2016].

Seawards from the Herald and Barrow canyons Atlantic Water is flowing eastward in a circumpolar cyclonic boundary current [Rudels et al., 2004], partly involved both in the Chukchi shelfbreak jet and in the Beaufort shelfbreak jet. Corlett and Pickart, 2017 surprisingly have also found out it flowing westward in the Chukchi Slope Current (see Section 4), and further investigations of this surprising aspect, the dynamics of the Chukchi Slope Current and processes off-shelf (e.g. eastward transport of the AW in the Canada Basin) are needed.
Meltwater was found mainly on the sections in the Herald Canyon during all of the discussed above surveys. It occupied the upper column and its salinity was different during various surveys because of different timings of the ice melt [Linders et al., 2017.

\section{Chukchi Slope Current and Shelfbreak Jet}

Pacific origin water, after passing through the shelf, enters the Canada Basin of the Arctic Ocean, but the exact mechanisms by which it exits the Chukchi Sea (and the geographical locations where this occurs) are still not fully understood. Two eastward flowing bottom-intensified shelfbreak jets are known to be formed with the water exiting the Barrow and Herald canyons. The first one (Beaufort shelfbreak jet, also referred to in the literature as the western Arctic Boundary Current, or the Pacific Water Boundary Current) follows the Beaufort slope all year round during upwellingfavorable winds - surface-intensified during latesummer/early-fall, bottom-intensified over the remainder of the year [Nikolopoulos et al., 2009, Pickart et al., 2005. Due to the lack of in situ measurements the latter one is less studied, but is believed to flow eastwards in the absence of strong wind forcing [Corlett and Pickart, 2017; Pickart et al., 2005. For example, by analyzing the data from the 2009 survey on the shelfbreak Pisareva et al. 2015a have concluded, that summer waters passing through the Herald Canyon in 2009 turned to the right and followed the bathymetry eastward.

Using a collection of historical shipboard sections across the Chukchi shelfbreak from the summer periods (from July to October) of 2002-2014, Corlett and Pickart 2017 have revealed the existence of a previously unquantified $50-\mathrm{km}$ wide surfaceintensified Chukchi Slope Current, proceeding westwards over the upper continental slope (see also synoptic measurements of Brugler et al., 2014). This baroclinically unstable current is believed to emanate from the Barrow Canyon, reminiscent of a free jet. While it mainly resides on the upper continental slope, it meanders and is not confined to a particular isobath. The strongest velocities are in the upper $150 \mathrm{~m}$, although the current extends deeper into the Atlantic layer. 
All of the Pacific origin waters (BSW, ACW, RWW) were found to be to some extent delivered by the Chukchi Slope Current, along with Arctic origin water present in the surface layer and Atlantic Water in the deep layer. By contrast, the largest amount of WW occurs within the shelfbreak jet. These results suggest that the Slope Current is a fast-track for advecting Pacific water out of the Barrow Canyon (in the warm months this would consist of RWW, BSW, and ACW), while the shelfbreak jet is a slower, longer route for Pacific water emanating from the Herald Canyon (hence WW is only showing up along the Chukchi shelfbreak at this time of year).

Transport estimates based on the mentioned dataset show that in the mean, the Slope Current transports $0.50 \pm 0.07 \mathrm{~Sv}$ of Pacific water, while the weaker and narrower eastward flowing shelfbreak jet accounts for $0.1 \pm 0.03 \mathrm{~Sv}$ [Corlett and Pickart, 2017. No significant variation in volume transport with distance both for the Chukchi Slope Current and the shelfbreak jet was found, hence Corlett and Pickart 2017] suggested that cross-shelfbreak subduction of mass is minimal.

While the year-round seasonal variability of both the Chukchi Slope Current and the Chukchi shelfbreak jet has not been yet investigated, it is evident, that substantial changes in winds over the Pacific Arctic influence the behavior of these currents, as well as the Beaufort shelfbreak jet [Corlett and Pickart, 2017, Pickart et al., 2010. It has been documented, that the Chukchi Slope Current increases in strength from summer into fall presumably due to the seasonal enhancement of the easterly winds in the region, while the shelfbreak jet weakens and can reverse direction from eastward to westward in October (which also coincides with the upwelling events in the Barrow canyon [ Lin et al., 2018]) - likely due to the same forcing [Corlett and Pickart, 2017, Lin et al., 2018. Using a year-long mooring array on the outer shelf and continental slope in the northeastern Chukchi Sea from 2013 to 2014 Li and Pickart 2017 revealed, that the Chukchi Slope Current is present throughout the year (transporting the AW year-round), but during winter and spring the flow weakens and is characterized by a sub-surface maximum in velocity.

According to the study of Corlett and Pickart 2017 the transport of Pacific summer waters by the Chukchi Slope Current increased from 2002-
2004 to 2009-2014 also likely in response to wind (the Chukchi shelfbreak transport decreased over the same periods) or due to the increased transport of Pacific Water through the Bering Strait [Woodgate et al., 2012].

The nature and forcing mechanisms (such as wind, inflow through the Bering Strait or the role of the Beaufort Gyre) of the Chukchi Slope Current still need further exploration. Corlett and Pickart 2017 have discussed, that this current is very likely not a part of the Beaufort Gyre. At the same time, evidences from various studies [Mizobata et al., 2016, Steele et al., 2004; Zhang et al., 2016 imply, that the two are dynamically dependent, which remains a intriguing question for future research.

\section{Summary}

While the book of Aagard, Coachman, and Tripp 1975 to this day remains one of the most extensive descriptions of the hydrography of the Chukchi Sea, on-going oceanographic research show, that the transport pathways on the Chukchi shelf are more complex than previously thought. Recent papers have shed more light onto the circulation patterns on the shelf: described the previously unknown Chukchi Slope Current, found anomalous flow pathways under strong wind forcing (e.g. Alaskan Coastal Water in the Herald canyon, or Atlantic Water near the Icy Cape), and discussed detailed Winter Water pathways. However, many questions still remain unanswered. Shallow bathymetry, seasonal presence of ice, and atmospheric forcing cause strong hydrographic variability of the sea on the variety of time scales. Both in-situ measurements and model studies are crucial in assessing vital changes in the Pacific inflow to the Arctic. Beneficial results obtained through the international and multidisciplinary collaborations in climate research justify the need and the importance of continuing the efforts towards better understanding the complex and dynamic system of the Pacific Arctic.

Acknowledgments. The paper was written in the framework of the state assignment of FASO Russia (theme No. 0149-2018-0003). It was supported in part by the Grant of the President of the Russian Federation 
for state support of young Russian scientists (no. MK6168.2018.5). The author would like to thank Kathy Crane for the long-term support of the RUSALCA program; Robert S. Pickart and Sergey V. Pisarev for the ongoing supervision and productive work on the projects; scientists and collaborators of the RUSALCA program; as well as the crews of the $\mathrm{R} / \mathrm{V}$ Professor Khromov and USCGC Healy.

\section{References}

Aagaard, K., A. T. Roach (1990), Arctic ocean shelf exchange: measurements in Barrow Canyon, J. Geophys. Res., 95, No. C10, 18,163-18,175.

Anderson, L. G., et al. (2011), East Siberian Sea, an Arctic region of very high biogeochemical activity, Biogeosciences, 8, No. 6, 1745-1754.

Bourke, R. H., R. G. Paquette (1976), Atlantic water on the Chukchi shelf, Geophys. Res. Lett., 3, 629-632, Crossref

Brugler, E. T., et al. (2014), Seasonal to interannual variability of the Pacific water boundary current in the Beaufort Sea, Prog. Oceanogr., 127, 1-20.

Carmack, E., I. Polyakov, L. Padman, et al. (2016), Toward Quantifying the Increasing Role of Oceanic Heat in Sea Ice Loss in the New Arctic, Bulletin of the American Meteorological Society, Crossref

Coachman, L. K., K. Aagaard, R. B. Tripp (1975), Bering Strait, The Regional Physical Oceanography, 172 pp. University of Washington Press, Seattle and London.

Cooper, L. W., T. E. Whitledge, J. M. Grebmeier, et al. (1997), The nutrient, salinity, and stable oxygen isotope composition of Bering and Chukchi Seas waters in and near the Bering Strait, J. Geophys. Res., 1021, No. C6, 12,563-12,574, Crossref

Corlett, W. B., R. S. Pickart (2017), The Chukchi Slope Current, Progress in Oceanography, 153, 5065, Crossref

Gong, D., R. S. Pickart (2015), Summertime circulation in the eastern Chukchi Sea, Deep-Sea Research, II, No. 118, 18-31, Crossref

Itoh, M., S. Nishino, Y. Kawaguchi, et al. (2013), Barrow Canyon volume, heat, and freshwater fluxes revealed by long-term mooring observations between 2000 and 2008, J. Geophys. Res. Oceans, 118, 4363-4379, Crossref

Itoh, M., R. S. Pickart, T. Kikuchi, et al. (2015), Water properties, heat and volume fluxes of Pacific water in Barrow Canyon during summer 2010, Deep Sea Res. I: Oceanographic Res. Papers, 102, 43-54, Crossref

Ladd, C., C. W. Mordy, S. A. Salo, et al. (2016), Winter Water Properties and the Chukchi Polynya, J. Geophys. Res. Oceans, 121, 5516-5534, Crossref
Li, M.,
R. S. Pickart
(2017),
Circulation of the

Chukchi Sea shelfbreak and slope from moored timeseries, Absract, Marine Science Symposium, Alaska. (http://www.nprb.org/assets/amss/images/uploads/ files/AMSS2017_BookofAbstracts.pdf)

Lin, P., R. S. Pickart, G. W. K. Moore, et al. (2018), Characteristics and dynamics of wind-driven upwelling in the Alaskan Beaufort Sea based on six years of mooring data, Deep Sea Research II Crossref

Linders, J., R.S. Pickart, G. Björk, et al. (2017), On the nature and origin of water masses in Herald Canyon, Chukchi Sea: Synoptic surveys in summer 2004, 2008, and 2009, Progress in Oceanography, 159, 99-114, Crossref

Lowry, K. E., R. S. Pickart, et al. (2015), The influence of winter water on phytoplankton blooms in the Chukchi Sea, Deep-Sea Res. II, 118, 53-72, Crossref

Marshall, J., C. Hill, L. Perelman, et al. (1997), Hydrostatic, quasi-hydrostatic, and non-hydrostatic ocean modeling, J. Geophys. Res., 102, 57335752 .

Mizobata, K., E. Watanabe, N. Kimura (2016), Wintertime variability of the Beaufort Gyre in the Arctic ocean derived from cryosat-2/siral observations, J. Geophys. Res.: Oceans, 121, 1685-1699, Crossref

Nikolopoulos, A., R. S. Pickart, P.S. Fratantoni, et al. (2009), western Arctic boundary current at $152^{\circ} \mathrm{W}$ : Structure, variability, and transport, Deep-Sea Res. II, 56, 1164-1181, Crossref

Okkonen, S. R., C. J. Ashjian, R. G. Campbell, et al. (2009), Intrusion of warm bering/chukchi waters onto the shelf in the western beaufort sea, J. Geophys. Res.: Oceans, 114, No. C00A11, Crossref

Pickart, R. S., T. J. Weingartner, L. J. Pratt, et al. (2005), Flow of winter-transformed water into the western Arctic, Deep Sea Research II, 52, 3175 3198, Crossref

Pickart, R. S., L. J. Pratt, et al. (2010), Evolution and dynamics of the flow through Herald Canyon, Deep-Sea Res. II, 57, No. 1-2, 5-26, Crossref

Pickart, R. S., G. W. K. Moore, Chongyuan Mao, et al. (2016), Circulation of winter water on the Chukchi shelf in early Summer, Deep-Sea Res. II, 130, 56-75, Crossref

Pisareva, M. N., R. S. Pickart, M. A. Spall, et al. (2015a), Flow of pacific water in the western Chukchi Sea: Results from the 2009 RUSALCA expedition, Deep-Sea Research I, 105, 53-73, Crossref

Pisareva, M. N., R. S. Pickart, et al. (2015b), The relationship between patterns of benthic fauna and zooplankton in the Chukchi Sea and physical forcing, Oceanography, 28, No. 3, 68-83, Crossref

Rudels, B., E. P. Jones, U. Schauer, et al. (2004), Atlantic sources of the Arctic Ocean surface and halocline waters, Polar Res., 23, 181-208.

Shimada, K., T. Kamoshida, M. Itoh, et al. (2006), Pacific Ocean inflow: Influence on catastrophic reduction of sea ice cover in the Arctic Ocean, Geophys. Res. Lett., 33, L08605, Crossref 
Spall, M. A. (2007), Circulation and water mass transformation in a model of the Chukchi Sea, J. Geophys. Res. Ocean, 112, 1-18, Crossref

Steele, M., J. Morrison, W. Ermold, et al. (2004), Circulation of summer Pacific halocline water in the Arctic Ocean, J. Geophys. Res., 109, C02027, Crossref

Weingartner, T. J., D. J. Cavalieri, K. Aagaard, et al. (1998), Circulation, dense water formation, and outflow on the northeast Chukchi shelf, J. Geophys. Res., 103, 7647-7661.

Weingartner, T.J., K. Aagaard, R. Woodgate, et al. (2005), Circulation on the north central Chukchi Sea shelf, Deep Sea Res., Part II, 52, 3150-3174.

Woodgate, R. A., K. Aagaard, T. J. Weingartner (2005a), Monthly temperature, salinity, and transport variability of the Bering Strait through flow, Geophys. Res. Lett., 32, L04601, Crossref

Woodgate, R. A., K. Aagaard, J. H. Swift, et al. (2005b), Pacific ventilation of the Arctic Ocean's lower halocline by upwelling and diapycnal mixing over the continental margin, Geophys. Res. Lett., 32, L18609, Crossref
Woodgate, R. A., T. J. Weingartner, R. Lindsay (2012), Observed increases in Bering Strait oceanic fluxes from the Pacific to the Arctic from 2001 to 2011 and their impacts on the Arctic Ocean water column, Geophys. Res. Lett., 39, L24603, Crossref

Woodgate, R. A., K. M. Stafford, F. G. Prahl (2015), A synthesis of year-round interdisciplinary mooring measurements in the Bering Strait (1990-2014) and the RUSALCA years (2004-2011), Oceanography, 28, No. 3, 46-67, Crossref

Wood, K. R., J. Wang, S. A. Salo, et al. (2015), The climate of the Pacific Artctic during the first RUSALCA decade: 2004-2013, Oceanography, 28, No. 3, 24-35, Crossref

Zhang, J., M. Steele, K. Runciman, et al. (2016), The Beaufort Gyre intensification and stabilization: a model-observation synthesis, J. Geophys. Res.: Oceans, 121, 7933-7952, Crossref

M. N. Pisareva, Shirshov Institute of Oceanology, Russian Academy of Sciences; 36, Nahimovskiy prospekt, Moscow, Russia, 117997, (mnpisareva@gmail.com) 